\title{
Towards a political economy of charging regimes: fines, fees and force in UK immigration control
}

\section{Jon Burnett and Fidelis Chebe}

Abstract: Charging regimes and the extraction of revenue are integral components of immigration control in the UK. However, while these have been analysed in their individual guises, to date there has been little substantive analysis bringing these regimes together and locating them at the centre of its enquiry. Drawing on data obtained through the Freedom of Information Act 2000, this paper consequently examines the functions of charging regimes as a distinct form of statecraft, focusing its attention on UKVI fees and charges, carrier sanctions, charges related to accessing services and civil penalties administered though immigration enforcement. Analysing their historical roots and their contemporary prevalence, it suggests that they contribute to political economy of financial power which has significant implications for understandings of criminalisation and immigration enforcement.

Keywords: charging regimes, civil penalties, immigration fees, immigration enforcement, carrier sanctions, crimmigration

This article examines something that is at the forefront of immigration control in the UK, but that has not always been at the forefront of the analysis of it: the raising of revenue and the extraction of value. Provisions for income collection through immigration control have a long history in the UK, with the 1905 Aliens Act, for example, enabling the Home Office to charge shipping companies for the costs of removing migrants (under certain circumstances) if they had earlier facilitated their arrival (see Bashford and Gilchrist 2012). However, over the last few decades, and the last few years in particular, the imposition of fees and fines has accelerated to a point where they sit at the centre of immigration policy and practice. The maximum value of civil penalties for those responsible for enforcing immigration control have increased (Home Office 2016a); and the range of bodies liable to receive such penalties has broadened (although not without opposition). Undocumented workers caught in enforcement operations can, for the first time, have their wages confiscated as proceeds of crime (Home Office 2017). An immigration health surcharge has been introduced, and charging regimes for those 'not ordinarily resident' have intensified (Department of Health 2017). Meanwhile, the costs levied on those applying for citizenship, leave to remain and visa services have in some cases increased exponentially (Project for the Registration of Children as British Citizens (PRCBC) and Amnesty International 2019); and fees introduced in immigration tribunals mean that appealing against immigration decisions is in some cases now dependent on the ability to afford doing so (HM Courts \& Tribunal Service 2017). In the process, a form of economic power has been embedded within almost every single aspect of immigration control within the UK, with its functions mandated - in some contexts - to ensure profitability.

What follows utilises empirical research to develop a conceptual and analytical account of this form of economic power. It draws from publicly available financial accounts and reports from bodies involved in the administration of immigration control where available; but it also makes extensive use of data obtained through the Freedom of Information Act (FOIA) 2000 where not. In the process, it examines a fiscal framework within which hundreds of millions of pounds of revenue are levied (or charged for) each year from those subject to immigration control or, in some contexts, responsible for its administration. This article explores how these charging regimes operate within and in some ways act as a connecting thread between a range of policy 
trajectories. It examines how they are utilised (among other things) to police the boundaries of service provision, ensure acquiescence with immigration control, cohere the public interest with regard to immigration enforcement and help fund immigration control itself. It scrutinises the ways in which they operate as an integral component of immigration and asylum control.

This acceleration of fees has not gone unnoticed by those working with people subject to immigration control (Valdez-Symonds 2018), human rights and activist groups (Bruce 2018; Docs Not Cops 2018; Let us Learn 2019; Patel and Peel 2017) and work published in academic fora exploring them in their specific forms (Aliverti 2016; Baird 2017; Steele et al. 2014). Indeed, such has been the groundswell of concern about certain charging functions that in 2019 the Independent Chief Inspector of Borders and Immigration (ICIBI 2019a: 9) published the results of an investigation which expressed alarm about their costs and the extent to which they are 'truly transparent'. Thus, it is certainly not the contention here that either the existence of particular fines, charges or fees - or their acceleration - has escaped attention. However, it is the contention that when brought together into a single analytical frame, they raise significant questions about a political economy of charging regimes at the core of British immigration control.

This article consequently attempts to sketch out the parameters of this political economy of charging regimes, and in doing so, it explores its implications for criminological inquiry. Initially, it examines the development of charging regimes in the UK. This provides a backdrop against which to map out their integration within a broader framework of immigration control, before outlining their total 'value' in one financial year: 2017-18. Drawing on this data, this article then expands its frame of analysis by discussing the role of charging regimes in shaping the parameters of migration before, in turn, examining the ways in which they operate in conjunction with immigration enforcement. Certainly, in quantitative terms, the sums generated through charging regimes utilised directly as a form of immigration enforcement make up only a small proportion of the sums generated through charging regimes in their entirety. However, as this article goes on to suggest, charging regimes ostensibly unrelated to immigration enforcement nonetheless have a key role within it. The substantial profits generated through certain UK Visas and Immigration (UKVI) fees, for example, can both create precarity, and also precipitate moves to punish it. Whilst simultaneously, charging regimes are integral to the ongoing blurring of the lines between immigration control and the functions of the welfare state. Consequently, as well as being utilised to trigger immigration enforcement, it is argued, charging regimes have had - and continue to have - significantly injurious effects on some of those unable to meet their costs, to the point where they have been fatal. Indeed, it is the contention of this article that understanding this is vital to understanding the ways in which charging regimes can underpin criminalisation and operate in conjunction with immigration enforcement.

According to the Home Office (2018a: 3), it is 'the Government's aim to achieve a self-funded immigration system' in the UK; and ultimately, this article examines the political economy of charging regimes that is central to attempts to achieve this. In doing so, it explores the social ramifications of a form of statecraft that is bound up integrally with harm and profit, precarity and punishment, and it explores the implications this has for contemporary understandings of crimmigration (Stumpf 2006).

\section{Charging regimes, fines and fees: mapping the parameters}


There is extensive literature on the history and development of immigration control in the UK which has documented, among other things, its colonial origins (Bashford and Gilchrist 2012; Sivanandan 1976), and its neo-colonial present (Webber 2012). Within these structural frameworks, charging regimes have operated in a range of ways to buttress broader political objectives. In as far back as 1793, for example, 'Britain required the masters of vessels to declare information about certain foreigners or face a fine’ (see Bloom and Risse 2014: 70). Whilst, as noted above, the Aliens Act 1905 contained provisions to fine the carriers of those who had transported people into the UK (in certain circumstances) who were later deported. Nonetheless, whilst the influence of the Aliens Act 1905 has been well documented - with Vincenzi (1985: 275) going as far as describing it as 'the start of modern immigration law' - it is the contention here that one of its key contributions was to form part of the basis of a regime of economic power that has since become central to immigration control. Manifested within a series of interlinked spheres, these are examined briefly in what follows.

\section{'Pre-border' and border controls}

Echoes of the Aliens Act 1905 can certainly be found in the development of carrier sanctions. The Immigration Act 1971, for example, contained provisions to make carriers liable to pay 'for the detention, accommodation and maintenance costs of certain passengers who had been refused entry, as well as their removal costs' (Scholten 2015: 72). Yet it was not until the enactment of the Immigration (Carrier's Liability) Act 1987 (ICLA) that carriers (such as airlines or shipping vessels) could be charged for every embarking person who was unable to produce adequate documentation - at a rate of $£ 1,000$ per passenger. Rushed through parliament by the Thatcher government, this legislation was utilised explicitly to widen the scope of those with responsibility for immigration control, establishing an increased threat of financial sanction to do so. Whilst, crucially, it was followed that same year by guidance on how to negotiate fee waivers for those carriers who cooperated with immigration authorities (Shah 2000: 145-8). That is, it acted as a concrete form of 'responsibilisation' (see Garland 2001) that has since become widespread within immigration control, encouraging cooperation and co-option through financial means (see Home Office 2006).

With fines doubling to $£ 2,000$ per person in the early 1990s, the revenue subsequently generated through carrier sanctions in this period was significant: between 1987 and 1998 fines totalling some $£ 117$ million were issued, according to one analysis, before a new carrier's liability civil penalty was set out in the Immigration and Asylum Act 1999 (Fiddick 1999: 467). It is this legislation that continues to act as the mechanism through which contemporary carrier sanctions are administered; and it does so in conjunction with penalties of up to $£ 10,000$ imposed on carriers that have brought in passengers deemed to pose a threat to national security introduced in 2012, and that were extended to $£ 50,000$ per breach three years later (see Home Office 2015a).

What is more, carrier sanctions were certainly not the only financial mechanisms being intensified towards the latter part of the twentieth century, and nor were they restricted to the UK. Countries in the global North increasingly looked to create ways to 'upstream' their border functions in the latter part of the 20 ${ }^{\text {th }}$ century (Reynolds and Muggeridge 2008: 4). And according to Shah (2000: 145), one of the drivers of the ICLA was anger amongst government ministers that the visa restrictions that were being imposed on people from countries considered to 'produce' larger numbers of asylum seekers were not substantially reducing the number of asylum claims. Indeed, while the use of carrier sanctions intensified in this period, they did so, 
in part, as a means to supplement visa requirements which, by preventing would-be refugees at the point of their departure, came to be conceptualised as the 'frontline of immigration control' (Reynolds and Muggeridge 2008: 25). There is little to suggest that their use and impact has lessened since. On the contrary, as will be outlined further below, the scope and range of visa costs has since expanded exponentially, coming to represent a core component of revenue collection and of shaping the contours of migration into the UK, of which a rationale to reduce irregular migration is only one component.

\section{Immigration policing and civil penalties}

The administration of charges at or beyond the border are an integral component of contemporary charging regimes then; but they have accelerated in tandem with a parallel civil penalty regime operating through immigration enforcement 'internally'. Under the Immigration Act 1971, it was already an offence for someone 'with limited leave to enter or remain within the UK to be in breach of any condition relating to his or her employment or occupation' (Fudge 2018: 573). However, the Asylum and Immigration Act 1996 and the Immigration, Asylum and Nationality Act 2006 expanded upon this by introducing penalties for employing people whose immigration status prevented them from working, of up to $£ 5,000$ and $£ 10,000$ respectively. These statutes manifested a desire to locate charging regimes at the centre of a key site of immigration enforcement (see Home Office 2013a), and in the context of the Conservatives' infamous drive to turn Britain into a 'hostile environment' for irregular migrants this subsequently intensified, both by way of the size of penalties and by way of scope. Under the Immigration Acts 2014 and 2016, civil penalties for employing undocumented workers increased to a maximum of $£ 20,000$ (Home Office 2016a), and were joined by 'right to rent' checks imposing penalties of up to $£ 3,000$ on landlords renting to irregular migrants (in conjunction, in certain circumstances, with custodial sentences; see Patel and Peel (2017). At the same time, a requirement for banks and building societies to check on the immigration status of some 70 million account holders per quarter began in early 2018, with the Financial Conduct Authority (FCA) given the power to use disciplinary measures (including financial penalties) for non-compliance. Against the backdrop of the widespread condemnation of the treatment of 'Windrush' migrants, these requirements were suspended just a few months later (although this suspension could itself be lifted at a later date, see Webber 2018: 11), and in 2019, the Home Office was forced to review its 'right to rent' measures following a High Court ruling that it was incompatible with the European Convention on Human Rights. However, an intention to appeal this decision was immediately made clear, and a commitment to utilising charging regimes as an integral component of the criminalisation of 'irregular' migrants also remains.

Indeed, as part of the growth industry of immigration offences in the UK (with 89 new offences created between 1999 and 2016 alone, for example; see Aliverti 2016), many have potentially attracted a fine (ranging from attempting to bring alcohol into an Immigration Removal Centre to assaulting a detainee custody officer). But it is under the Immigration Act 2016 that the extraction of revenue appears to have been asserted as a core factor of particular offences themselves. This legislation established 'illegal working' as a criminal offence, for example, attracting a fine or a custodial sentence (or both) and also enabling the earnings of workers to be confiscated under the Proceeds of Crime Act 2002 (Home Office 2017a: 9). At the same time, it was under this legislation that an offence of driving while unlawfully resident was created, with those convicted liable for a custodial sentence and a fine under the Road Traffic Act 1988. 


\section{Accessing services and UKVI fees}

Charging regimes have further been incorporated into key sites of 'service provision' itself. Central to this is health care, and in 2015, an Immigration (Health Charge) Order was added to visa and immigration applications, requiring those subject to immigration control (with certain exemptions) to pay an annual surcharge of up to $£ 200$ to contribute to NHS costs. This doubled to $£ 400$ (in certain circumstances) at the beginning of 2019 (see Home Office 2018b). Access to health care has long been a key battleground with regard to migrants' rights and responsibilities, of course; and in the 1980s hospital costs for overseas visitors were introduced, with those not deemed 'ordinarily resident' required to pay for certain forms of care. However, these requirements have 'gradually been expanded since' (Doctors of the World 2017a: 3). The National Health Service (Charges to Overseas Visitors) (Amendment) Regulations 2017, for example, made hospital departments in England legally responsible for checking patients' eligibility and for charging 'upfront' for care. If patients cannot prove their eligibility for treatment that is free at the point of delivery (and that is not urgent or immediately necessary), fees of up to $150 \%$ of the cost of care can be sought after as part of the Department of Health's (2017: 8) 'ambition' of making up to $£ 500$ million per year. Yet charging for certain forms of healthcare works in conjunction with charging for a further pillar of the welfare state: legal support. Following a consultation in 2010 on introducing charges for appeals in the Immigration and Asylum Chambers of the First-tier Tribunal and the Upper Tribunal, fees for most appeals against immigration decisions (again, with certain exceptions) were introduced in 2011, set in 2017 at $£ 80$ for appeals heard on paper and $£ 140$ for oral hearings (HM Courts \& Tribunal Service 2017). In the process, the ability to challenge decisions made about a range of immigration issues was made dependent on being able to afford to do so. And it is in this context that charging for 'services' has coalesced with a development of fees and charges attached to what the Home Office describes as 'UK based applications for permanent settlement and nationality applications in-country’ (Home Office 2018c: 99).

In September 2018 there were 132 distinct Home Office immigration and nationality fees, categorised under eight separate groupings of: visas and applications made outside the UK; points based system - applications made outside the UK; optional premium services made outside the UK; optional premium services in the UK; optional premium services at the border; applications made in the UK; points based system - applications made in the UK; and points based system - sponsorship (see UKVI 2018). As such, these fees and charges include both 'in-country' charges and those made externally (highlighted above) which, while operating in most cases to lever costs on migrants themselves, also include charges imposed on migrants' employers and sponsors. For its own financial purposes, the Home Office breaks down UKVI costs into separate categories of 'international group - visas' and 'immigration group - in country'; and by utilising these categories, in conjunction with the charging regimes set out above, it is possible to begin to map out an architecture of charging regimes within immigration control and the sums generated within this schema.

\section{Methodology and scope}

Against this backdrop, this article draws upon several distinct forms of information in order to examine empirically and analytically the charging regimes in UK immigration control. Where possible, it utilises Home Office annual accounts as primary data in order to ascertain the revenues generated. Leading from this, it draws upon immigration enforcement 'transparency data', published in conjunction with a 'transparency agenda' instigated by the coalition 
government after it came to power in 2010 (see Cabinet Office 2013). However, while ostensibly originating with an aim of 'strengthening public accountability', this 'agenda' has been criticised by the Home Affairs Cabinet Committee (among others) for providing data that is 'poor or incomplete' and with 'gaps in information' (House of Commons Committee of Public Accounts 2012: 3): criticisms that are salient here. These data say nothing about moneys raised through certain forms of criminalisation, for example, and they say very little about forms of monetarisation that are not administered through the Home Office. Indeed, rather than making transparent a series of financial regimes, some forms of information are partial, and others are absent.

As such, this article also utilises already published secondary data if available. But it further makes significant use of information gathered under the FOIA through a series of requests made in a six-month period between October 2018 and March 2019 for the purposes of this research. These requests attempted to extract data from the Ministry of Justice (MOJ), the Home Office, Immigration Enforcement (IE), the Crown Prosecution Service (CPS), the NHS, NHS Improvement, the Department of Health and Social Care, the Ministry of Housing, Communities and Local Government and HM Courts and Tribunal Service about the charging regimes above. They asked a series of questions relating primarily to: the total sums received in the latest year at the time of writing, the total sums received in the years over a longer period (up to either five or ten years), the differences between moneys received and moneys claimed for over these periods, the functions of fees, and information about fee remissions. That they were sometimes met without success is indicative of Tombs and Whyte's (2003: 225) reminder that those engaged in critical research should be mindful of 'the abilities of state servants to exercise influence or control over the outcomes of that research'. Indeed, more than one request was refused or answered only in partial form on the basis of exceeding the upper cost limit of FOI expenditure, 'system limitation', not holding the desired information or not having 'sufficiently detailed management information'. Nonetheless, in conjunction with information gleaned from the sources above, from the data that was released it is possible to give both a broad baseline of the sums raised or issued as part of immigration control in the most recent financial year at the time the FOI data was gathered: a scale of revenue that in 2017/18 amounted to some $£ 1.754$ billion. 
Figure 1 - Charging regimes in immigration enforcement, immigration control and access to services: a select overview (2017-18 unless otherwise stated)

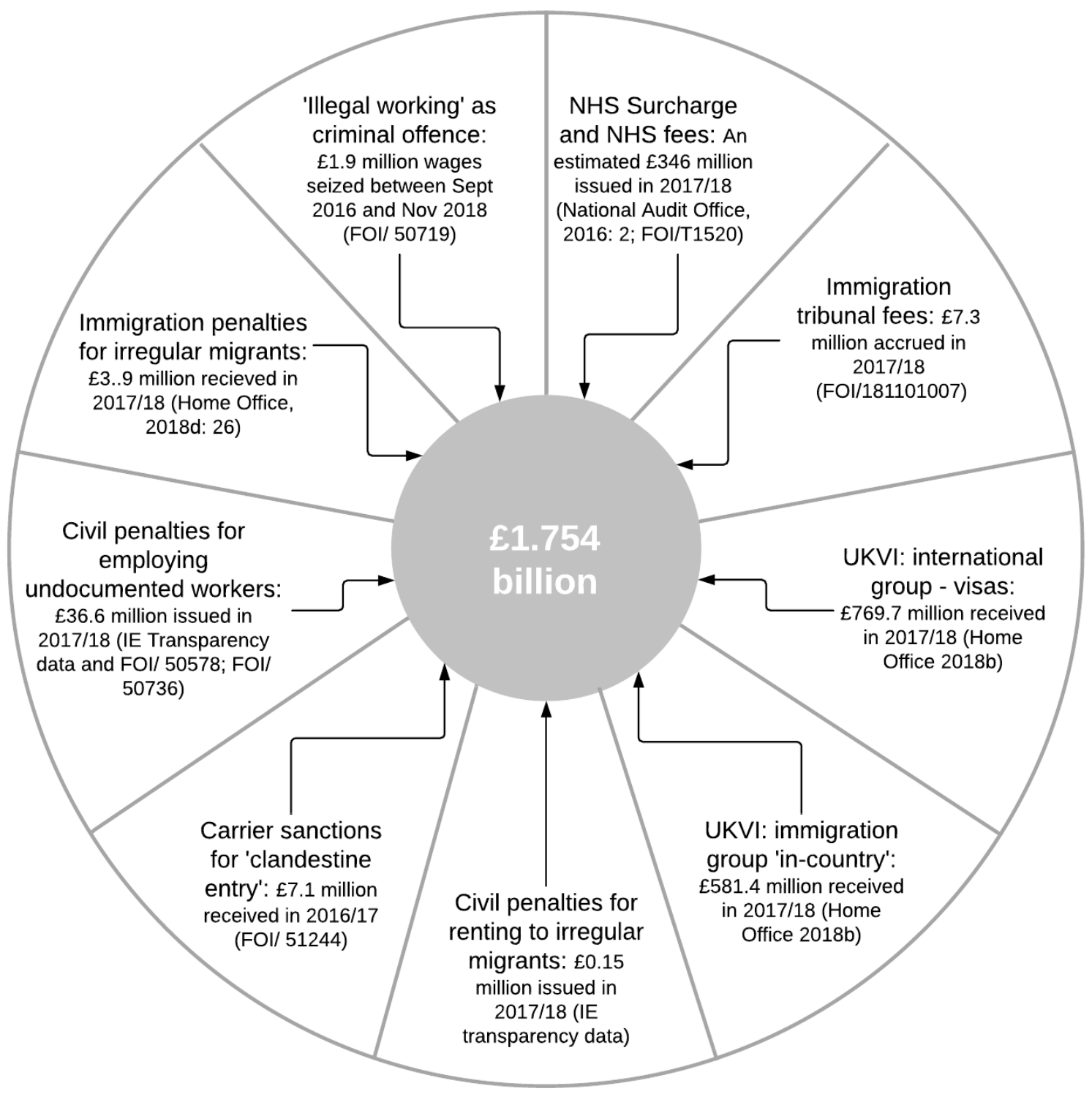

It is important to note that this figure is certainly under-representative. It does not include fines collected through all immigration offences in the year given (of which there are over 150 in existence), for example; and it simplifies certain revenue streams made up of a range of fees and costs (particularly those relating to UKVI) by presenting their combined value. Furthermore, the Home Office (2018d: 20) received $£ 91.372$ million from the Immigration Skills Charge in 2017/18, but this is not included as it is 'collected as part of the Tier 2 visa applications' and it is consequently assumed here that this is already included in its presentation of UKVI fees. Also, given that the 'UKVI Immigration Group deals with UK based applications for permanent settlement and Nationality applications' for the purposes of Home Office annual reports and accounts (2018c: 99), it excludes revenue generated through HM Passport Office (of which there was some $£ 521.5$ million in 2017/18 alone). 
In turn, it should also be noted that the distinction in terminology ('issued', 'received', 'charged for' and 'accrued') is important (the figure for tribunal fees, for example, is that which has been calculated after fee remissions have been taken into account). Whilst finally, the combined 2017/18 NHS surcharge and other fees figure is based on predicted revenue by the Audit Office, rather than verified revenue (with information about charges to visitors liable for NHS treatment made available through FOI data, but not the totals revenues raised through the surcharge itself). Yet, as crude as it is, it is nonetheless indicative - in the first instance - of an immense form of financial power embedded within immigration control in the UK. It sets out a fiscal environment within which income generation is asserted as a principle strategy of immigration control, and in doing so enables an exploration of how this intersects with broader aims and trajectories. It is to this that attention next turns.

\section{Towards a political economy of charging regimes}

Central to this fiscal framework is the manner in which the extraction of value from those subject to immigration control has come to occupy a central rationale and organising principle of immigration policy itself. There is little ambiguity with this, and as the Home Office has stated, it is envisaged that 'the costs of front-line Border, Immigration and Citizenship operations are to be recovered through fees paid by those who use the system' (Home Office 2018c: 3). Consequently, attempts to ensure full cost recovery for the operation of the immigration system coalesces directly with HM Treasury's guidelines on Managing Public Money (MPM): a guide for government departments (among other bodies) on public expenditure advocating charges to recoup the costs incurred for the administration of particular services (HM Treasury 2013). Indeed, underpinned as this is by a desire to cement market rationality within state services, this guidance argues that charging can make 'comparisons with private sector services easier, promote competition, develop markets and generally promote financially sound behaviour in the public sector' (Ibid 2013: 41).

Against this backdrop, it is important to emphasise that the ability to charge 'over cost' fees was first introduced by the New Labour government in 2004 (and then applied from 2007 onwards; see ICIBIa 2019: 34). As an ideological and economic strategy, then, it has roots stretching back well over a decade. However, as Figures 2 and 3 indicate below, in the years since the return to power of a Conservative (or Conservative-led) administration in 2010, the sums generated suggest not only an enthusiastic embrace of a desire for the 'cost recovery' articled above. They demonstrate a desire to exceed it, generating (in some contexts at least) substantial and unprecedented profit in the process. With regard to income for the Home Office from UKVI in-country applications and the UKVI international group, for example, fee recovery targets have been set incrementally, with a general upwards trend (albeit with some deviation). In 2017/18 they sought to almost double the cost of their administration (194 per cent of the costs, to be precise). As such, when examining 'income from services provided to external and public sector companies’ (Home Office 2018c: 98), this went from a £81.409 million surplus in 2009-10 to £252.063 million in 2017-18 for UKVI in-country applications, and from a $£ 17.195$ million deficit to a $£ 375.170$ million surplus for the UKVI international group in the same period (see Home Office 2010; 2011a; 2012; 2013b; 2014; 2015b; 2016b; 2017b; 2018c). Meanwhile, the income the Department of Health and Social Care received from the Home Office with regard to the immigration health surcharge increased by 76 per cent between 2015/16 and 2017/18, from £117.806 million to £207.161 million (FOI/116358); and that was prior to the doubling of the charge at the beginning of 2019. 
Figure 2 - Home Office income from services provided to the UKVI Visas and Immigration International group - Visas: 2009-10 to 2017-18

\begin{tabular}{|l|l|l|l|l|l|}
\hline Year & $\begin{array}{l}\text { Income/ } \\
\text { revenue } \\
£ 000\end{array}$ & Full cost & Profit & $\begin{array}{l}\text { Fee } \\
\text { recovery } \\
\text { actual }\end{array}$ & $\begin{array}{l}\text { Fee } \\
\text { recovery } \\
\text { target (\%) }\end{array}$ \\
\hline $2017-18$ & 769,690 & 394,520 & 375,170 & 195 & 194 \\
\hline $2016-17$ & 705,376 & 364,158 & 341,218 & 194 & 192 \\
\hline $2015-16$ & 637,112 & 379,810 & 257,302 & 168 & 169 \\
\hline $2014-15$ & 585,500 & 393,216 & 192,284 & 149 & 148 \\
\hline $2013-14$ & 528,245 & 449,195 & 79,050 & 118 & 100 \\
\hline $2012-13$ & 444,759 & 366,571 & 78,188 & 121 & 100 \\
\hline $2011-12$ & 428,520 & 416,510 & 12,030 & 103 & 100 \\
\hline $2010-11$ & 399,321 & 407,319 & $-7,998$ & 98 & 100 \\
\hline $2009-10$ & 283,739 & 300,934 & $-17,195$ & 94 & 100 \\
\hline Total & $\mathbf{4 , 7 8 2 , 2 6 2}$ & $\mathbf{3 , 4 7 2 , 2 3 3}$ & $\mathbf{1 , 3 1 0 , 0 4 9}$ & & \\
\hline
\end{tabular}

Figure 3 - Home Office income from services provided to the UKVI Immigration group in-country costs: 2009-10 to 2017-18

\begin{tabular}{|l|l|l|l|l|l|}
\hline Year & $\begin{array}{l}\text { Income/ } \\
\text { revenue } \\
£ 000\end{array}$ & $\begin{array}{l}\text { Full cost } \\
£ 000\end{array}$ & $\begin{array}{l}\text { Profit } \\
£ 000\end{array}$ & $\begin{array}{l}\text { Fee } \\
\text { recovery } \\
\text { actual } \\
(\%)\end{array}$ & $\begin{array}{l}\text { Fee } \\
\text { recovery } \\
\text { target (\%) }\end{array}$ \\
\hline $2017-18$ & 581,464 & 329,401 & 252,063 & 177 & 194 \\
\hline $2016-17$ & 476,999 & 279,322 & 197,677 & 171 & 192 \\
\hline $2015-16$ & 449,663 & 271,290 & 178,343 & 166 & 201 \\
\hline $2014-15$ & 429,300 & 198,936 & 230,364 & 216 & 239 \\
\hline $2013-14$ & 524,300 & 208,428 & 315,872 & 252 & 189 \\
\hline $2012-13$ & 482,599 & 200,283 & 282,276 & 241 & 184 \\
\hline $2011-12$ & 433,734 & 206,072 & 227,662 & 210 & 184 \\
\hline $2010-11$ & 413,364 & 221,408 & 191,956 & 187 & 184 \\
\hline $2009-10$ & 320,953 & 239,544 & 81,409 & 134 & 100 \\
\hline Total & $\mathbf{4 , 1 1 2 , 3 7 6}$ & $\mathbf{2 , 1 5 4 , 6 8 4}$ & $\mathbf{1 , 9 5 7 , 6 2 2}$ & & \\
\hline
\end{tabular}

There is an official justification for such seismic shifts, of course, couched in a language of fairness and arguing that fee increases contribute to the costs of providing services and thus reduce the 'burden' on those paying tax. For instance, an impact assessment for the Immigration and Nationality (Fees) Order 2016 stated that the 'government believes it is right that those who use and benefit directly from the UK migration system make an appropriate contribution to the meeting of its costs, thereby reducing the call on UK tax payers' (Home Office 2015c: 3). In turn, with regard to the immigration health surcharge, the Immigration Minister when it was expanded stated that the NHS 'is a national, not international health service' and that migrants need to contribute 'to its long-term sustainability' (Home Office 2018b). However, such claims are problematic. As Potter (2017: 418-9) has stated: 'Whilst 
working, [migrants] pay income tax and National Insurance, as well as VAT and other consumption taxes they will pay even if not working'. Furthermore, while 'debate' on migration is often locked into a reductive discussion over the extent to which migrants provide economic benefits or not, what these strategies could perhaps more accurately be described as is the imposition of sometimes punishing fees and charges on immigration status itself.

It is notable, then, that many of those charges rapidly intensified against the backdrop of the austerity measures implemented from 2010 onwards. For while migrants were certainly already vilified as a drain on public resources prior to this period, this certainly intensified further (see Burnett 2017). Meanwhile, the role of the state was the subject of sustained debate and attention (see Cooper and Whyte 2017), with the Prime Minister David Cameron suggesting in 2015 that the fiscal environment engendered by the financial crisis provided the opportunity for the emergence of a 'smarter state' where 'achieving a surplus' was a priority, and where 'it's not just about resources: it's about results' (Cameron 2015a). Although this 'smarter state' should not be 'run exactly like a business', he suggested, it should nonetheless 'use their insights' (Ibid). And in this regard, while this is certainly not to suggest that the climate of austerity was the sole or even driving factor behind this rapid intensification of charging regimes, it nonetheless at least contributed to its impetus. Indeed, it is somewhat ironic that while 'charges in certain contexts 'substitute for taxation (or, in the short term, borrowing) as a means of government finance’, according to HM Treasury’s (2013: 41) MPM framework, the charging regimes described above constitute a unique form of 'migration tax' in their own right.

\section{Charging regimes and controlling immigration strategies}

How, though, does this commitment to transforming the existence and administration of migration into a form of profit on the one hand, square with the stated aims of reducing (at least some forms of) migration itself on the other? After all, this has been the explicit goal of successive governments, which have consistently staked a claim to control and cohere overall migration as electoral strategy (see, for example, Cameron 2015b; May 2018). In order to explore this question, it is necessary to examine the fluidity of charging regimes and their multifaceted nature. For they serve different purposes, at different times, and in relation to the particular immigration status within which they are focused.

In 2015, the Home Office (2015c: 3) was candid about this fact, stating that 'the government aims to limit fee increases on the most economically beneficially sensitive routes in order to continue to attract those migrants and visitors whom add significant value to the UK economy'. And as it later suggested, 'Some fees are also set at below cost where a lower fee supports wider government objectives' (Home Office 2018c: 3). Therefore, while the Home Office extracts profits of over 800 per cent for some visa fees, the development of UKVI charges above should not just be seen as creating profit for profit's sake (although this is not to ignore capital's 'boundless and measureless urge to exceed its own limits', in Marx's (1986/1857-8: 260 ) words). What has been created is a fiscal framework within which fees and charges are imposed strategically, with charges relating to some immigration services (and migrants themselves) particularly punishing so as to facilitate and contribute to others.

For example, an Immigration Skills Charge introduced in 2017 - initially set at a cost of £1,000 per worker levied on employers - was 'explicitly intended to make foreign workers uncompetitive in order to reduce immigration' (Yeo 2017). This charge was 'large enough to have an impact on employer behaviour', according to the government's Migration Advisory Committee; before claiming that it was set at 'the right level to incentivise employers to reduce 
their reliance on migrant workers' (Ibid). However, in conjunction with such charges, when commenting on visa application fee changes in 2016, one legal firm noted that a two per cent increase in application fees for those 'seen as being linked to economic growth' (such as certain workers or visitors) was offset by a twenty-five per cent increase in fees for settlement, residence and nationality. Thus 'bearing in mind' a twin political desire to make Britain 'attractive to businesses' whilst making the immigration system self-funding (at least), the rationale behind these changes, it continued, was clear. The aim was to 'limit increases in fees for students, visitors and workers so as not to deter people from coming the UK in the first place', it suggested, while simultaneously making up 'the deficit by imposing hefty hikes on non-EEA nationals who have already established a life in the UK and want to remain' (Clarkslegal 2016).

Fees to apply for indefinite leave to remain more than doubled between 2009 and 2018, for instance, from $£ 1,020$ to $£ 2,389$, despite their estimated 'unit cost' being set at $£ 243$ in that latter year according to UKVI (2018). Meanwhile, fees for UK naturalisation applications increased from $£ 200$ in 2005 to $£ 1,282$ in 2017 (Yeo 2017). And with settlement visas for adult dependent relatives costing some $£ 3,250$ in 2018 (and 'regularising' under the 20-year-rule costing over $£ 10,000$ in order to do so), it is unsurprising that some commentators have argued that 'settlement and citizenship are increasingly affordable only to the wealthy' (Webber, 2018: 22-3). For against a backdrop where the Home Office (2011b) has 'rolled out the red carpet for entrepreneurs and investors' who contribute to 'economic growth', charging regimes have become integral to managed migration policies (and their more recent incarnations) which manifest a desire to bend migration patterns to market needs as one of their core rationales (for discussion, see for example Anderson 2013). What remains in the rest of this article explores the implications that this - in conjunction with charging regimes more broadly - has for criminalisation, enforcement and crimmigration.

\section{Crimmigration, charging regimes and immigration enforcement}

Initially developed as a means through which to understand the convergence of crime control and immigration control (see Stumpf 2006), the notion of crimmigration has provided an important conceptual framework through which to comprehend developments on a range of fronts over the last few decades. These include (but are certainly not restricted to) the overlapping of criminal and immigration law, the ways in which immigration enforcement has come to resemble criminal law enforcement, and the extent to which procedural mechanisms in responding to immigration violations have come to mirror aspects of criminal procedure (Ibid 2006: 381). In the UK, these trajectories have emerged in conjunction with the mass expansion of the detention estate and the proliferation of a range of forms of surveillance, among other shifts. And such is the depth of these developments that Bowling (2013: 304) has suggested that a 'crimmigration control industry' has been established over this period that is 'dangerous and damaging to human lives'.

Operating as a means to shape the parameters of immigration, charging regimes make a concrete contribution to this crimmigration control industry, in the first instance, through the ways in which they can underpin significant precarity, exacerbate marginalisation and create the conditions for exploitation. According to Sigona and Hughes (2012: vii), for instance, there were approximately 120,000 children with an irregular immigration status in the UK in 2012, of whom 65,000 were born to 'irregular migrant parents'. And although this latter group can theoretically apply for citizenship if they have lived in the UK for ten years continuously, the 
costs to do so stood at $£ 1,012.12$ in 2019, of which $£ 640$ consisted of profit for the Home Office (PRCBC and Amnesty International 2019). What is more, in many cases, children and young people will need to have been granted limited leave to remain throughout this decade prior to even being able to apply for citizenship in the first place: a status which needs renewing every thirty months and which costs over $£ 2,000$ per renewal (CCLC and Let us Learn 2018). As such, the impact on those caught up within this is profound. For, as the ICIBI (2019a: 38) has highlighted, the exorbitant costs of fees relating to settlement and leave to remain have left people 'unable to lead "a normal life"', have 'adversely affect[ed] their mental and physical wellbeing', and have routinely created 'feelings of anxiety, humiliation, isolation and inferiority'. Such is the financial cost burdened on people simply trying to regularise their immigration status that they have left parents having to choose between children. They have forced people into significant debt and indebted to predatory lenders. They have directly underpinned 'exploitative situations' by, for example, rendering people vulnerable to unscrupulous employers; and in at least some cases they have driven people into destitution. (Ibid).

At the same time, UKVI fees have not only forced significant numbers of people into debt and created the conditions for exploitation. They have rendered them vulnerable to removal. With many people unable to meet the cost of these fees, they can have - and have had - a direct role in events culminating in attempts to deport people to countries they have barely visited, for minor transgressions of the law (Dugan 2019). It is against this backdrop that lawyers have argued they 'destroy the futures of children who've grown up British, for profit' (ValdezSymonds, cited in England 2019). For they can create the precarity that immigration enforcement punishes. Indeed, while the charging regimes noted above might not be designed to lead to criminalisation, in their role in attempts to make the (relative) security of immigration status contingent (in part) on capital, they have in at least some cases resulted in the criminalisation of those without.

\section{Criminalisation and the welfare state}

Of course, an inability to pay UKVI fees is not the primary force underpinning immigration enforcement in the UK. Nor is this to suggest that they always embed precarity and criminalisation. However, it is to say that the capacity to do so is inherent within them. Fees are non-refundable if applications are refused, and while in some cases they can be waivered if an applicant is destitute, for those under 25 less than one per cent of requests for fee waivers are granted (CCLC 2018: 3). Furthermore, not only is legal aid for support completing them generally unavailable. The introduction of charging regimes into immigration appeals appears to have curtailed access to a fundamental means of challenging negative immigration decisions, including, but certainly not restricted to those regarding applications for settlement and leave to remain. While the Courts and Tribunals Service received $£ 10.6$ million (after fee remissions) in 2014/15 for appeals relating to immigration matters, for example, the $£ 7.3$ million received in 2017/18 was a reduction of almost a third (FOI/ 181101007).

However, if this points to one of the ways that charging regimes are utilised as part of ongoing shifts in the welfare state, this is certainly not restricted to access to justice. In particular, charging regimes within the NHS work simultaneously to impose costs on those subject to immigration control and to trigger immigration enforcement explicitly against those liable for removal. This was made clear in 2017, when a memorandum of understanding (MOU) between the Department of Health and the Home Office revealed how non-clinical patient data gathered 
for the purposes of assessing eligibility to NHS care was being shared with the Home Office for enforcement purposes. And while this was abandoned (after a backlash) in 2018, the Home Office was still accessing patients' data about NHS debts and using it to underpin immigration enforcement in 2019, in some cases facilitating their detention (ICIBI 2019b).

It is hardly surprising then that in 2017, over half of the 43,000 people across Europe who reported to Doctors of the World (2017b) that fear of arrest was an impediment to accessing healthcare were UK-based. For the double-function of charging regimes sever the boundaries between care and control; and much like with UKVI fees, this has had devastating consequences in the process. According to Doctors of the World (2017a: 2), for example, healthcare charging regimes in England for those deemed not to be 'ordinarily resident' have deterred 'heavily pregnant women and people suffering from cancer, diabetes, cataracts, kidney failure, fibroids and post-stroke complications' from accessing treatment. Meanwhile, as Maternity Action has documented, pregnant women and mothers with babies have been locked into abusive, sometimes physically violent relationships as a result of health charges, as they have felt that they must rely on their partner to meet the payment of NHS debt (Feldman 2017). Indeed, such is the extent of harm inherent within these charging regimes that in some cases they have proved fatal. In 2018, an elderly woman with cancer died after an NHS Trust in England demanded £30,000 'upfront' before starting chemotherapy. Her family were unable to meet these costs, and their 'desperate' offer of paying $£ 500$ a month in instalments was rejected (Jayanetti 2018). Similarly, when a man with an irregular immigration status who had suffered heart failure was admitted to hospital in 2018, he was refused a transplant but nonetheless charged $£ 16,000$ for receiving end-of-life care. Unable to pay, he died a few months later, at which point his family were invoiced for a further $£ 55,000$ (Nye 2019). Between 2013/14 and 2017/18 the income to the NHS for care for 'overseas patients' increased almost four-fold, from $£ 24$ million to $£ 87$ million (FOI/T1520). But as Skinner and Salhab (2019) have noted it is 'undocumented migrants, refused asylum seekers, and others caught up in the UK's dysfunctional and discriminatory immigration system' who are least likely to be able to meet the costs of NHS charges. Indeed, it is those same groups, in many cases, who have been denied care as they cannot meet its costs, avoided it through fear, or have ultimately been pursued by debt collections companies to whom the NHS has sold their outstanding debt.

\section{Crimmigration and 'institutional violence'}

In at least certain guises, then, it would surely be no exaggeration to see charging regimes as a manifestation of what Cooper and Whyte (2017: 23; emphasis in original) have elsewhere described as 'institutional violence': a 'means of force which is not simply acted upon, but organised and administered through legitimate means'. With institutional violence 'bureaucratised' within " "ordinary" and "mundane” processes that routinely and over time deteriorate ... physical and mental health', they suggest, 'it is the threat of violence that has become absolutely central to the force that institutional violence wields over its targets' (Ibid). And in this regard, it is particularly pertinent as a means of analysis here. For it is indicative of a framework within which charging regimes can cause significant harm upon their recipients whilst, at the same time, working in conjunction with a broader politics of criminalisation and immigration enforcement.

This has particular resonance in a context where the terrain of immigration enforcement is shifting. That NHS charges have been integral to the drive to turn the UK into a 'hostile environment' for irregular migrants is well established. At its core, this embodies a desire to 
coerce irregular migrants from the country by denying them (or reducing) access to services; and extending as it does into a range of spheres, this policy framework has consequently been integral to attempts to enforce 'compliance' with immigration control in ways that reduce reliance on immigration enforcement itself (Home Office 2018d: 9). However, what is also well established is that even on its own terms there is 'little evidence that the hostile environment policies introduced in 2014 have encouraged a larger number of people to leave' (Walsh 2016: 6). Indeed, while there were 40,179 enforced and 'voluntary' returns in 2014, this had reduced to 24,510 four years later (Ibid: 4-5). In turn, this reduction in removals has coincided with a similar fall in civil penalties imposed upon those responsible for immigration enforcement; and whilst the total number of 'right to rent' penalties issued in the 2016 calendar year (when they came into force) had a combined value of $£ 73,500$, for example, they had reduced by some 36 per cent to $£ 46,750$ two years later. Meanwhile, the combined value of civil penalties issued to employers with regard to undocumented working reduced by 57 per cent, from $£ 49.4$ million to $£ 21$ million in the same period.

The reasons for this are multifaceted. For example, the hostile environment policy framework has been met with well-publicised critique and resistance (see, for example, Global Justice Now 2018; Liberty 2018) which, among other things, has been central to the High Court declaring the right to rent checks unlawful in 2019. Whilst the 2018 'Windrush scandal' has 'had a significant effect on Immigration Enforcement', according to the ICIBI (2019c: 2), even if only temporarily. At the same time, the reduction in civil penalties levied on employers might also be related to their use as a financial lever to facilitate cooperation with immigration control itself. For as Bales (2017: 288) has demonstrated, their end point is the creation of an environment wherein 'employers, who have no legal duty to expose their staff to Immigration Enforcement raids, are incentivized to do so' (such as by turning in undocumented workers). Meanwhile, the Home Office's strategy of publicising the details of (uncooperative) employers of undocumented workers was described by the UKBA in 2007 as having a communicative as much as a material function: that is, a desire to 'increase public confidence' in the 'UKBA's work' by providing reassurance that its work is 'robust' (UKBA 2007). Indeed, whether the hostile environment is 'effective' in encouraging removals or not is not, in and of itself, the main point. For the rationale of charging regimes utilised in conjunction with this does not just reside in prompting removals, but in their subsidiary functions which operate in tandem.

Of course, this also includes an economic rationale. For the income generated through immigration penalties levied on 'individuals who enter or remain illegally in the UK' (in the Home Office's (2018d: 26) terminology) ultimately contribute to the consolidated fund (the 'central account administered by HM Treasury' (Ibid 6)). So too do the wages of undocumented workers seized though the Immigration Act 2016 as proceeds of crime, civil penalties that are levied on carriers and employers and the health surcharge. But as indicated above, it is precisely those without capital who are less likely to be able to pay. The British Medical Association (BMA 2019) is among those NHS bodies which have called for the abolition of upfront NHS charges for those 'not ordinarily resident', for instance: in part because they can leave those unable to meet their costs requiring more complex, and costly, care. Similarly, the $£ 1.9$ million of wages seized from undocumented workers between September 2016 (when the relevant legislation was enacted) and November 2018 (FOI/50719) is paltry in comparison to other charging regimes. Yet the revenue alone is not the issue: this also serves a punitive function, contributing to broader attempts to make residing in the UK intolerable, where it is not made impossible. Indeed, while immigration ministers may have claimed to be 'detoxifying' immigration policies following the Windrush scandal - not least through rebranding the hostile environment as a 'compliant environment' (for discussion, see Wemyss 2018) - this, at best, 
is open to question. For the continued commitment to utilising charging regimes on those vulnerable to immigration enforcement indicates a further function existing outside of the aims of enforcement itself: the disciplining of vulnerable populations.

What the above analysis suggests then, at the very least, is that there is a need to explore the extent to which immigration enforcement and criminalisation are both connected to and mediated by a broader framework of charging regimes. Certainly, the charging regimes that are utilised explicitly as a form of immigration enforcement make up only a minor component of this broader anatomy in its entirety. But this analysis indicates that those ostensibly unrelated to enforcement can nonetheless have a role in underpinning it, triggering it and operating in conjunction with it. As such, examining a political economy of charging regimes not only foregrounds the extent and functions of a vast form of economic power, it also asks questions of the place and role of criminalisation within this. What is clear is that charging regimes can, and in many cases do, cause harm and anguish in their role cohering migration, policing access to services and - in some cases - creating profit from immigration status itself. What is also clear is that they are integral to ongoing, deep-rooted shifts within the welfare state which, in turn, asserts it as a key site of immigration control. In short, it is the contention of this article that by analysing a political economy of charging regimes, this begins to reveal a form of statecraft which is integral to immigration policy. And whilst this, of course, is not to suggest that it is its driving force. What it is to say is that it has hitherto largely been unexamined in the $\mathrm{UK}$, and by bringing it to the forefront of attention this begins to foreground both its relevance for contemporary immigration control and its implications for contemporary analyses of crimmigration.

\section{Conclusion}

Over the last few decades, a burgeoning body of literature has been produced on immigration and asylum control to the extent that they have become integral components of the criminological landscape (Arriaga 2016; Bosworth 2017). This has raised broad and vital questions, encompassing the normalisation of immigration detention and deportation (Weber 2002), the gendered impacts of the asylum system (Canning 2017), the relationships between citizenship and punishment (Bosworth and Guild 2008), the criminalisation of immigration law (Stumpf 2006) and the enlisting of the public in immigration policing (Aliverti 2015), among many other things. Within the scope of these frameworks of analysis, the political economies of immigration control have consistently been central. In the UK, for example, the state's attempts to force destitution upon 'irregular migrants', the politically-driven welfare chauvinism and the subcontracting of a plethora of functions of immigration control - with contracts frequently running into the hundreds of millions - is well established (Bacon 2005; Schuster and Bloch 2005).

This analysis suggests that the charging regimes operating at the centre of asylum and immigration policy ought to be afforded the same level of scrutiny. Clearly, a political economy of financial power exists at the heart of immigration control within the UK, and it is the contention here that understanding it as such is essential in order to eradicate its injustices. Despite a frightening amassing of power in recent years, as well as a commitment to locating charging regimes at the centre of immigration policy (HM Government 2018), this is not an impossible challenge. As examined earlier, the 'hostile environment' has proved ideologically and legally vulnerable. Meanwhile, in March 2019, the Home Office froze most immigration and nationality fees - even if only temporarily - in a move that was at least partly down to campaigning organisations (see, for example CCLC, 2019). If nothing else, this is indicative 
of the mounting concern about the inequities of charging regimes, their functions and their implications. This article hopes to make a modest contribution to understanding them.

\section{Acknowledgements}

The authors would like to thank the two anonymous reviewers, as well as Monish Bhatia, Kevin Boateng, Melissa Mendez and David Whyte for their invaluable advice and comments.

\section{Bibliography}

Aliverti, A. (2015), 'Enlisting the Public in the Policing of Immigration', British Journal of Criminology, 55/2: 215 - 230.

Aliverti, A. (2016), Immigration offences: trends in legislation and criminal and civil enforcement. Migration Observatory.

Anderson, B. (2013), Us and them? The dangerous politics of immigration control. Oxford University Press.

Arriaga, F. (2016), 'Understanding Crimmigration: Implications for Racial and Ethnic Minorities Within the United States’, Sociology Compass, 10/9: 805 - 812.

Bacon, C. (2005), 'The evolution of immigration detention in the UK: the involvement of private prison companies’, Refugee Studies Working Paper No. 27. Refugee Studies Centre.

Baird, T. (2017), 'Carrier Sanctions in Europe: A Comparison of Trends in 10 Countries', European Journal of Law and Migration, 19: 317 - 334.

Bales, K, (2017), 'Immigration raids, employer collusion and the Immigration Act 2016', Industrial Law Journal, 46/2: 279 - 288.

Bashford, A. and Gilchrist, C. (2012), 'The Colonial History of the 1905 Aliens Act', Journal of Imperial and Commonwealth History, 40/3: 409 - 437.

Bloom, T. and Risse, V. (2014), 'Examining hidden coercion at state borders: why carrier sanctions cannot be justified’, Ethics \& Global Politics, 7/2: 65 - 82.

BMA (2019), 'BMA says charging regulations for overseas patients are threatening the quality of NHS care', BMA Press Release, 18 April, https://www.bma.org.uk/news/mediacentre/press-releases/2019/april/bma-says-charging-regulations-for-overseas-patients-arethreatening-the-quality-of-nhs-care

Bosworth, M. (2017), 'Border Criminology and the Changing Nature of Penal Power', in A. Liebling, S. Maruna and L. McAra, eds., The Oxford Handbook of Criminology, (6 ${ }^{\text {th }}$ ed), 373 - 390. Oxford University Press.

Bosworth, M, and Guild, M. (2008), 'Governing through migration control: Security and citizenship in Britain’ British Journal of Criminology, 48/6: 703 - 719.

Bowling, B. (2013), 'Epilogue: The Borders of Punishment: Towards a Criminology of Mobility', in K. F. Aas, and M. Bosworth., The Borders of Punishment: Migration, Citizenship and Social Exclusion, 291 - 306. Oxford University Press. 
Bruce, G. (2018), 'Healthcare charging - unethical practice, unacceptable outcomes', MEDACT, 28 February: https://www.medact.org/2018/blogs/healthcare-charging-unethicalpractice-unacceptable-outcomes/

Burnett, J. (2017), 'Austerity and the Production of Hate', in V. Cooper, and D. Whyte., The Violence of Austerity, 217 - 223. Pluto Press.

Cabinet Office (2013), Transparency FAQs, London: Cabinet Office.

Cameron, D. (2015a), 'My vision for a smarter state', Speech to Leeds ONE, 11 September: https://www.gov.uk/government/speeches/prime-minister-my-vision-for-a-smarter-state

Cameron, D. (2015b), 'PM speech on immigration', Speech ahead of the Queen's speech, 21 May: https://www.gov.uk/government/speeches/pm-speech-on-immigration

Canning, V. (2017), Gendered Harm and Structural Violence in the British Asylum System. Routledge.

Clarkslegal (2016), 'Visa fees increase up to 25\% this month', Clarkslegal, (9 March), https://www.clarkslegal.com/Legal_Updates/Read/Visa_fees_increase_by_up_to_25_this_m onth

Cooper, V. and Whyte, D. (2017), The violence of austerity. Pluto Press.

CCLC (2018), The fee barrier: can you afford the place you call home? CCLC.

CCLC (2019), 'Home Office freezes immigration and nationality fees', CCLC, 12 March, https://www.childrenslegalcentre.com/home-office-fees-2019/

Coram Children's Legal Centre and Let us Learn (2018), 'Chief Inspector of Borders and Immigration review of Home Office fees Evidence', CCLC, July, https://www.childrenslegalcentre.com/wpcontent/uploads/2018/07/ICIBI_inspection_charging_CoramLetUsLearn_July_2018.pdf

Department of Health (2017), Making a fair contribution: Government response to the consultation on the extension of charging overseas visitors and migrants using the NHS in England. Department of Health.

Dugan, E. (2019), 'This Man Faces Deportation For Carrying Cannabis Despite Living In Britain Since He Was 4', Buzzfeed, 31 May, https://www.buzzfeed.com/emilydugan/homeoffice-deportation-citizenship-crime

Docs Not Cops (2018), 'No borders in healthcare', Docs Not Cops, 5 July, http://www.docsnotcops.co.uk/blog/

Doctors of the World (2017a), Deterrence, delay and distress: the impact of charging in NHS hospitals on migrants in vulnerable circumstances. Doctors of the World.

Doctors of the World. (2017b), Falling Through the Cracks: The Failure of Universal Healthcare Coverage in Europe. Doctors of the World.

England, C. (2019), 'The Government Is Profiting From Child Citizenship Applications Whilst Destitute Families Struggle To Eat', Rightsinfo, 5 April, https://rightsinfo.org/the-governmentis-profiting-from-child-citizenship-applications-whilst-destitute-families-struggle-to-eat/ 
Feldman, R. (2017), The Impact of Health Inequalities of Charging Migrant Women for NHS Maternity Care: a Scoping Study, Maternity Action

Fudge, G. (2018), 'Illegal working, migrants and labour exploitation in the UK', Oxford Journal of Legal Studies, 38/3: 557 - 584.

Garland, D. (2001), The culture of control: crime and order in contemporary society, Oxford University Press.

Global Justice Now (2018), The hostile environment for immigrants: how Theresa May has created an underclass in the UK. Global Justice Now

HM Courts \& Tribunal Service (2017), Fees Guidance First-tier Tribunal (Immigration and Appeals Chamber). HM Courts \& Tribunal Service.

HM Government (2018), ‘The UK’s future skills-based immigration system’, Cm 9772. HM Government.

HM Treasury (2013), Manging Public Money, HM Treasury.

Home Office (2006), Carriers’ Liability Charging. Home Office.

Home Office (2010), 'Resource Accounts 2009-10’, HC 193. Home Office.

Home Office (2011a), ‘Annual Report and Accounts 2010-11’, HC 985. Home Office.

Home Office (2011b), 'Government rolls out the red card for entrepreneurs and investors', Home Office Press Release, 16 March, https://www.gov.uk/government/news/governmentrolls-out-red-carpet-for-entrepreneurs-and-investors

Home Office (2012), ‘Annual Report and Accounts 2011-12’, HC 45. Home Office.

Home Office (2013a), Full guide for employers on preventing illegal working in the UK. Home Office.

Home Office (2013b), ‘Annual Report and Accounts 2012-13’, HC 21. Home Office.

Home Office (2014), ‘Annual Reports and Accounts 2013-14’, HC 21. Home Office.

Home Office (2015a), Authority to carry scheme. Home Office.

Home Office (2015b), ‘Annual reports and accounts 2014-15’, HC 12. Home Office.

Home Office (2015c), 'Impact Assessment for the Immigration and Nationality (Fees) Order 2016’ IA No: HO0216. Home Office.

Home Office (2016a), Immigration Act 2016 Factsheet - Illegal Working. Home Office.

Home Office (2016b), ‘Annual Reports and accounts’, HC 340. Home Office.

Home Office (2017a), An employer's guide to right to work checks. Home Office.

Home Office (2017b), ‘Annual Reports and Accounts’, HC 20. Home Office.

Home Office (2018a), 'Impact Assessment for Immigration and Nationality (Fees) Regulations 2018’, IA No: HO0310. Home Office. 
Home Office (2018b), 'Increase to NHS surcharge gives NHS extra funding', Home Office News Story, 11 October, https://www.gov.uk/government/news/increase-to-immigrationhealth-surcharge-gives-nhs-extra-funding

Home Office (2018c), ‘Annual Reports and Accounts’, HC 1136. Home Office.

Home Office (2018d), ‘Trust Statement 2017-18', HC 1832. Home Office.

House of Commons Committee of Public Accounts (2012), 'Implementing the transparency agenda: Tenth Report of Session 2012-13’, HC 102. The Stationary Office.

ICIBI (2019a), An inspection of the policies and practices of the Home Office's Borders, Immigration and Citizenship Systems relating to charging and fees. ICIBI.

ICIBI (2019b), An inspection of Home Office (Borders, Immigration and Citizenship System) collaborative working with other government departments and agencies. ICIBI.

ICIBI (2019c), An inspection of the Home Office's approach to Illegal Working August December 2018. ICIBI.

Jayanetti, C. (2018), 'NHS denied treatment for migrants who can't afford upfront charges', The Guardian, 13 November, https://www.theguardian.com/society/2018/nov/13/nhs-deniedtreatment-for-migrants-who-cant-afford-upfront-charges

Let us Learn (2019), 'Letter to Caroline Noakes', Let us Learn, 28 January, http://letuslearn.study/1413-2/

Liberty (2018), A guide to the hostile environment: the border controls dividing our communities - and how we can bring them down. Liberty.

Marx, K. (1986/1857/58), Karl Mark, Frederick Engels collected works: volume 28, Lawrence \& Wishart.

May, T. (2018), 'Theresa May's full speech to 2018 Conservative conference', Speech to Conservative Party Conference, Birmingham, 3 October, https://www.bbc.co.uk/news/av/ukpolitics-45733093/theresa-may-s-full-speech-to-2018-conservative-conference

Nye, C. (2019), 'NHS fees: “Couple couldn't take baby's body home”, BBC News Online, 10 July: https://www.bbc.co.uk/news/health-48907130

Patel, C. and Peel, C. (2017), Passport Please: the impact of the right to rent checks on migrants and ethnic minorities in England. Joint Council for the Welfare of Immigrants.

Potter, J. (2018), 'Patients not passports - no borders in the NHS!', Justice, Power and Resistance, 2(2), pp. $417-429$.

Project for the Registration of Children as British Citizens and Amnesty International (2019), Briefing on Fees for the Registration of Children as British Citizens. PRCBC and Amnesty International.

Scholten, S. (2015), The Privatisation of Immigration Control through Carrier Sanctions: The Role of Private Transport Companies in Dutch and British Immigration Control. Brill Publishers. 
Schuster, L. and Bloch, A. (2005), 'Asylum policy under New Labour', Benefits, 13/2: 115 118.

Shah, P. (2000), Refugees, race and the legal concept of asylum in Britain. Cavendish.

Sigona, N. and Hughes, V. (2012), No Way Out, No Way In: Irregular migrant children and families in the UK. University of Oxford.

Sivanandan, A. (1976), 'Race, class and the state: the black experience in Britain', Race \& Class, 17/4: 347 - 368.

Steele, S. Stuckler, D. Mckee, M. and Pollock, A. (2014), 'The Immigration Bill: Extending charging regimes and scapegoating the vulnerable will pose risks to public health', Journal of the Royal Society of Medicine, 107/4, pp. 132 - 133.

Skinner, J. and Salhab, A. (2019), 'How NHS staff are fighting back against the "hostile environment”, Open Democracy, 17 May: https://www.opendemocracy.net/en/ournhs/hownhs-staff-are-fighting-back-against-the-hostile-environment/

Stumpf, J. (2006), 'The Crimmigration Crisis: Immigrants, Crime, and Sovereign Power', American University Law Review, 56/2: 368 - 419.

Tombs, S. and Whyte, D. (2003), 'Unmasking the crimes of the powerful', Critical Criminology, 11/3, pp. 217 - 236.

UKBA (2007), Illegal working civil penalties: policy for publishing details of non-compliant employers. UKBA.

UKVI (2018), 'Home Office immigration and nationality fees April 2018 (updated September 2018)’, UKVI, https://www.gov.uk/government/publications/visa-regulations-revisedtable/home-office-immigration-and-nationality-fees-2018

Valdez-Symonds, S. (2018), 'Profiting from children's rights', Amnesty International, 8 June: https://www.amnesty.org.uk/blogs/ether/profiting-childrens-rights

Vincenzi, C. (1985), 'The Aliens Act 1905', New Community, 12/2: 275 - 284.

Walsh, P. (2019), Deportation and Voluntary Departure from the UK. University of Oxford.

Webber, F. (2012), Borderline Justice: the Fight for Refugee and Migrant Rights. Pluto Press.

Webber, F. (2018), The embedding of state hostility: a background paper on the Windrush scandal. Institute of Race Relations.

Weber, L. (2002), 'The detention of asylum seekers: 20 reasons why criminologists should care’, Current Issues in Criminal Justice, 14: 9 - 30.

Wemyss, G. (2018), “Compliant environment': turning ordinary people into border guards should concern everyone in the UK', The Conversation, 20 November, https://theconversation.com/compliant-environment-turning-ordinary-people-into-borderguards-should-concern-everyone-in-the-uk-107066 
Yeo, C. (2017), 'How expensive are UK immigration applications and is this a problem?', Freemovement, 17 August, https://www.freemovement.org.uk/how-expensive-are-ukimmigration-applications-and-is-this-a-problem/ 